\title{
Tackling Pharma corruption in Ukraine
}

\author{
Cite as: CMAJ 2017 August 28;189:E1101-2. doi: 10.1503/cmaj.1095454
}

Posted on cmajnews.com on Aug. 9, 2017.

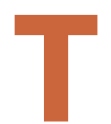

wo years after reforms started to curb corruption in the country's national drug procurement process, Ukraine's old guard is still pushing back - and still holds court at the regional level.

In 2015, Ukraine's Ministry of Health started a four-year program to outsource drug procurement to international organizations, including UNICEF and the United Nations Development Program. The goal was to root out longstanding corruption in the country's drug procurement process, wherein politicians, ministry bureaucrats and pharmaceutical distributors worked together to inflate prices.

"It was always one of the fastest and easiest ways to take money," says Olga Stefanyshyna, executive director of the advocacy group, Patients of Ukraine.

Under the old system, Stefanyshyna explains, corrupt officials and politicians would pocket an additional markup on drug prices. Ukraine's security services recently estimated that about $40 \%$ of the Ministry of Health's spending on drug procurement was lost as "black cash."

Thanks to the reforms this is no longer the case at the national level. In the first year with international organizations looking after drug procurement, the ministry saved the equivalent of almost $\$ 40$ million.

"It's been a very successful reform," Stefanyshyna says, "but it's always attacked by the people who made money on it."

Oleksandra Ustinova from Ukraine's Anti-corruption Action Centre (AntAC) is all too familiar with these kinds of attacks. She has led the nongovernmental organization's efforts to expose ongoing corruption in Ukraine's medical sphere, and in the drug procurement processes in hospitals and local regions, which are not part of new drug procurement process.

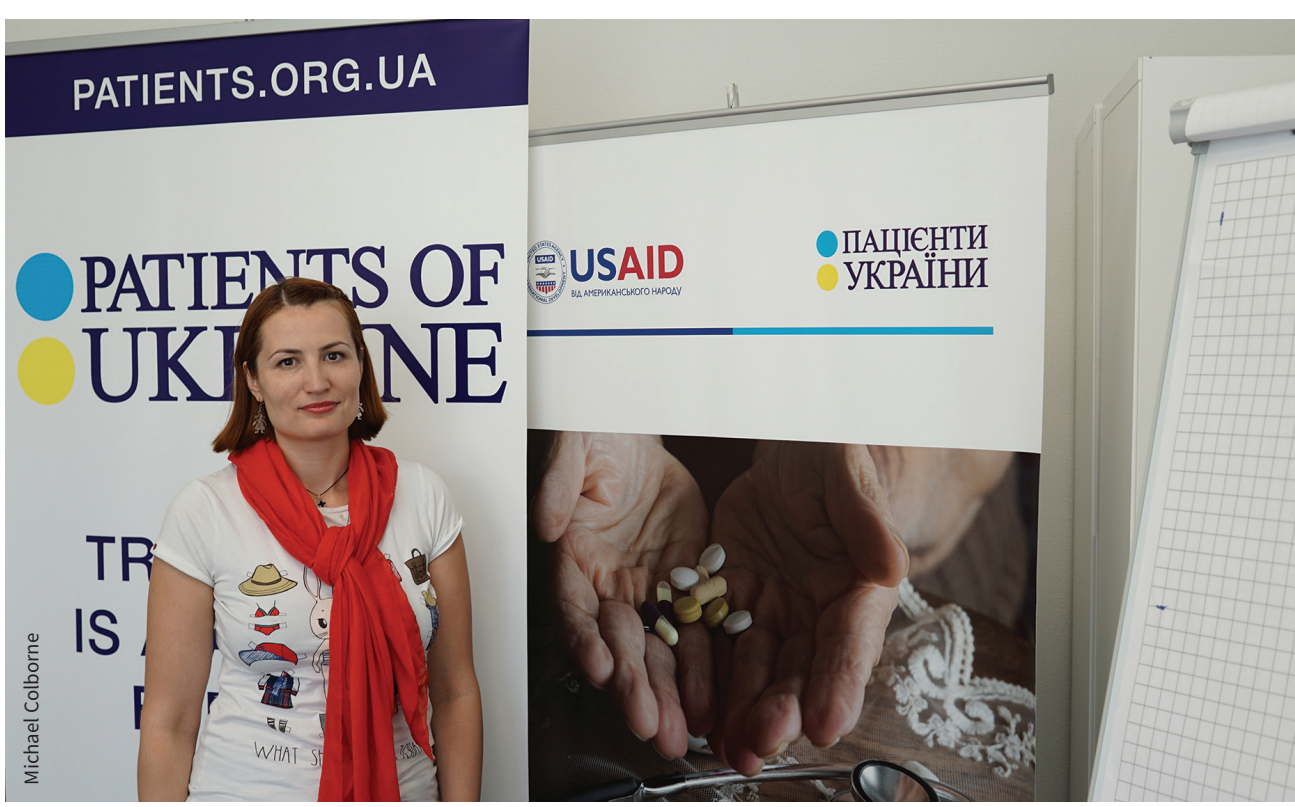

Successful reforms are under attack by those who stand to make money, says Olga Stefanyshyna of Patients of Ukraine.

Recently a self-proclaimed group of "justice seekers" accused Ustinova of pocketing money from international donors to AntAC. Claiming to be journalists, these so-called justice seekers confronted Ustinova at Kyiv's international airport where she was arriving from a vacation, and asked how she was able to afford it.

They also accused her of abandoning her country during a time of war. Having lost a friend in the war with combined Russian-separatist forces in eastern Ukraine, this accusation reduced Ustinova to tears. They then accused her of "learning to cry on camera."

Despite this treatment, Ustinova doesn't shy away from pointing out how the drug procurement process led by international organizations has been a success compared to what she says is still the corruption-plagued procurement across Ukraine at the regional and local level.
The price of drugs in regional hospitals is about $30 \%$ to $40 \%$ higher than the same drugs procured through international bodies, says Ustinova. "For some drugs it's up to $100 \%, 200 \%$ more at the regional hospital level."

Even Health Minister Ulana Suprun has felt the full force of the pushback against the drug procurement reforms. Suprun, a Ukrainian-American physician who became minister after the reforms began in 2015, contrasts the current situation with that under Viktor Yanukovych, the former president who fled the country after the revolution on the Maidan in February 2014.

"The tenders [then] were extremely corrupt, but not once did deputies in Parliament complain or send letters asking for any investigation," says Suprun.

"But since international organizations have taken over procurement we've had multiple investigations by state security, 
the state prosecutor's office, the National Police and oversight committees in Parliament," she says. The Ukrainian Parliament's audit committee has come to the Ministry of Health three times ostensibly to investigate drug procurement.

These investigations, which have not yet found anything of substance, are part of what Suprun says is "a huge backlash" in response to the drug-procurement reforms. Suprun says this is because many deputies, politicians and bureaucrats have lost illicit sources of income, or are still financed or on the payroll of what she calls Ukraine's "pharma mafia."
"They're trying to make the process slow down so that it looks unsuccessful," she says, noting that the current arrangement with international organizations ends in 2019.

This is all despite the reform's successes to date. Savings of $\$ 22$ million on oncology drugs alone has allowed Ukraine to buy 30 million more doses of tuberculosis drugs without an increase in budget, according to Suprun.

The drug procurement and other health reforms haven't always gone as well as hoped says Suprun, because of Ukraine's arcane, bureaucratic budgetary processes and lack of electronic health systems. But Suprun remains optimistic about improving Ukraine's inefficient health system. A wideranging set of proposed reforms will be voted on by Parliament later in 2017, which will include instituting a western-style health insurance system and completely changing the way the system is financed.

"Ukraine's health system hasn't changed for 25 years, says Suprun. "But in the last nine months we're finally on the verge of completely changing the health care system in Ukraine."

Michael Colborne, Kyiv, Ukraine 